\title{
Coding of Tissue Preparations with Eurocode in Germany
}

\author{
Ralf Knels $^{a}$ Hans-Joachim Mönig ${ }^{b}$ Georg Wittmann ${ }^{c}$ Rüdiger von Versen ${ }^{d}$ Axel Pruss ${ }^{e}$ \\ ${ }^{a}$ Eurocode International Blood Labeling System e.V., Dresden, \\ ${ }^{\mathrm{b}}$ DIZG - Deutsches Institut für Zell und Gewebeersatz, Berlin, \\ 'Institut für Transfusionsmedizin, Zelltherapeutika und Hämostaseologie, Klinikum der LMU München-Großhadern, München, \\ ${ }^{\mathrm{d}} \mathrm{V}$ V C von Versen International Consultants, Wandlitz, \\ ${ }^{e}$ Gewebebank, Institut für Transfusionsmedizin; Charité - Universitätsmedizin Berlin, Germany
}

\section{Keywords}

Eurocode - Tissue $\cdot$ Coding systems .

Look back · European Directive 2006/86/EC

\section{Summary}

A safe look back of products requires their unique identification. Blood products are encoded in Germany with Eurocode since 1987. EU Directives 2004/23/EC und 2006/86/EC demanded unique identification and safe look back procedure also for tissues and cells. Eurocode IBLS e.V. and the DGTI working parties 'Tissue Preparations' and 'Automation and Data Processing' supplemented the already available Eurocode nomenclature for blood products with further data structures for tissue preparations and deliberated the federal authorities during the EU hearings. In result all EU member states can administer the coding system oneself, but have to take care about the 'key code' structure as defined and the common part at the begin of the ID number of the preparations. Eurocode today offers an EU-conform coding system considering various aspects of blood, tissue and cell preparations in an ISO-standardized form.

\section{Introduction}

The transplantation of human tissues and cells is a strongly expanding field of medicine which offers great opportunities for the treatment of as yet incurable diseases. The European

\author{
Schlüsselwörter \\ Eurocode - Gewebe - Kodierungssysteme . \\ Rückverfolgbarkeit · Europäische Direktive 2006/86/EC
}

\section{Zusammenfassung}

Eine sichere Rückverfolgbarkeit von Produkten kann nur gewährleistet werden, wenn diese eindeutig gekennzeichnet sind. Für Blutprodukte wird in Deutschland dazu seit 1987 der Eurocode eingesetzt. Mit den EU-Direktiven 2004/23/EG und 2006/86/EG wurde die Forderung nach eindeutiger Kennzeichnung und sicherer Rückverfolgbarkeit auch für Gewebe und Zellen erhoben. Eurocode IBLS e.V. und die DGTI-Sektionen "Gewebezubereitungen" sowie "Automation und Datenverarbeitung" erweiterten die bereits für Blutprodukte vorhandene Eurocode-Nomenklatur um weitere Datenstrukturen für Gewebe und Zellen und berieten die Bundesbehörden bei den Verhandlungen in der EU. Im Ergebnis besteht für alle Mitgliedsländer die Möglichkeit, das Kodiersystem unter Berücksichtigung einer einheitlichen, vorgegebenen Schlüsselstrukur («key code») am Beginn der Präparatenummer selber zu verwalten. Der Eurocode bietet heute die Möglichkeit der EU-konformen Kodierung verschiedener wesentlicher Aspekte von Blut- Gewebe- und Zellpräparationen in einem ISO-standardisierten System.

Community should therefore endeavor to promote the highest possible level of protection to safeguard public health regarding quality and safety of tissues and cells [1]. The worldwide exchange and the potential risk for transmission of infection diseases throughout these products needs clear rules for

\section{KARGER \\ Fax +497614520714 \\ Information@Karger.de}

www.karger.com (c) 2012 S. Karger GmbH, Freiburg

1660-3796/12/0396-0409\$38.00/0

Accessible online at:

www.karger.com/tmh
Dr. med. Dr. Med. Univ. Pécs Ralf Knels

Eurocode International Blood Labeling System e.V.

Oehmestraße 5, 01277 Dresden, Germany

knels@eurocode.org 
traceability, which can ensured only with correct identification of affected products.

The necessity of clear identification and traceability is today widely accepted not only for blood products, tissue and cells, but also for other medical duties. Barcodes are today the most common solution for the quick and safe capture of the encoded information. With the assistance of the International Organization for Standardization (ISO), various documents have been published which indicate how coding and traceability can be internationally standardized, without the diverse interest groups being dependent on only one supplier. One main element of these coding systems is formed by the data and application identifier, whose structure is determined by a joint document of the ISO and the International Electrotechnical Commission (IEC). This document ISO 15418 specifies sets of data identifiers and application identifiers for the purpose of worldwide unique data identification and determines the organizations responsible for their maintenance [2]. Thus, data encoded by following these rules are worldwide unique. This offers the opportunity to use this standard as a baseline for the coding of tissues and cells, which are worldwide exchanged.

The quality and safety of these substances should be guaranteed, particularly in order to prevent the transmission of diseases.

\section{Data Structures and Barcode Formats}

\section{Data Identifier in Accordance with ISO/IEC 15418}

The ISO Committee have been adopted the respective system identifiers of the AABB (American Association of Blood Banks), the International Society of Blood Transfusion (ISBT), and the Eurocode International Blood Labeling System e.V. (Eurocode IBLS) into the ISO/IEC 15418. Thus the organizations have the sole right to insert their special character at the beginning of a code. The AABB (\&) and the ISBT $(=)$ have transferred their symbols to the ICCBBA for use in the ISBT 128 [3], although they are still registered by the ISO as the organization with the responsibility of maintaining the respective system. The data structures following the '!' are regulated by the Eurocode IBLS. The advantage of these data identifiers is that the subsequent data structures are clearly distinguished from other coding systems used within the industry and the health sector.

\section{Barcode Technology}

A barcode is an optical machine-readable representation of data. The coded data structure can be read automatically, quickly and safely. There are different forms and types of barcodes. In addition to the widely used linear bar codes, stacked bar codes and two-dimensional bar codes are also sometimes employed. The latter has the main advantage of being able to store more information.

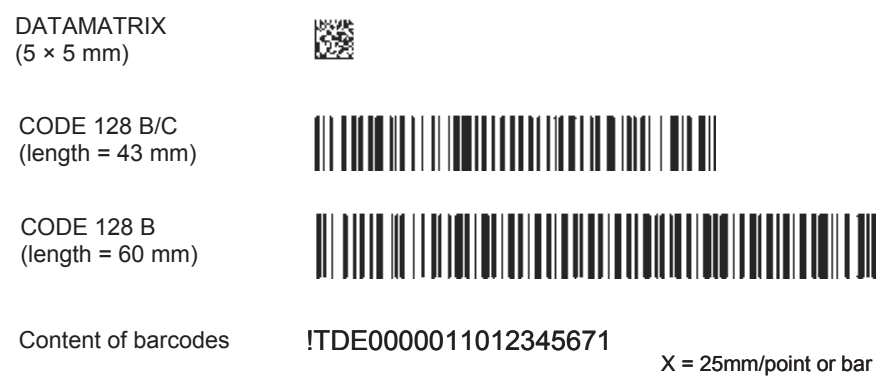

Fig. 1. Proposed Eurocode unique product identification number in different barcode formats.

The linear bar code standard Code 128 provides excellent density for all-numeric data and good density for alphanumeric data. Eurocode makes use of this barcode format, as this ensures a reliable and efficient reading of the barcode. A further advantage of Code 128 is that it is possible in subset $\mathrm{C}$ to place two digits in one optical character, thereby saving space and facilitating the reading of the code with standard barcode readers (fig. 1).

DATAMATRIX is an example of a two-dimensional bar code which allows encoding of additional data elements such as product code and expiry date in one bar code.

CODE 128 B/C starts in Subset B followed after switching with a special control character by Subset C; Subset B uses one character for each symbol and encodes in this example the ASCII symbol '!' and the letters; Subset C compresses two numeric digits into each character, providing excellent density and a shorter length as Subset B.

CODE 128 B uses one character for every symbol and in this example for the digits too, resulting in longer bar code.

Due to their data structures which incorporate primary and secondary data identifiers, Eurocode can be easily implemented into two-dimensional barcodes. Thus all relevant product information can be encoded in one barcode and read in one easy step. Special barcode scanners are required to read two-dimensional bar codes, as the laser-based bar code scanners which are today popular in medical institutions are unsuitable. This limitation is currently a serious impediment to the use of two-dimensional barcodes in the medical sector.

\section{Eurocode Structure}

Eurocode IBLS was founded in 1998 and is a non-profit organization under German Tax Law. Eurocode IBLS is responsible for the maintenance of the Eurocode, which is established today as a coding system for blood and other products of human origin in 124 facilities in Germany and Croatia. The technical committee strove to incorporate current ISO standards and other standardizations during the development of the code structures.

The uniqueness of all Eurocode data structures is ensured by the primer data identifier '!' in accordance with ISO/ IEC 15418 . 


\begin{tabular}{|c|c|c|c|}
\hline EU DG SANCO WG & $\begin{array}{l}\text { Country ID } \\
+ \text { TE }\end{array}$ & $\begin{array}{l}\text { Unique Donation } \\
\text { number }\end{array}$ & Product Code \\
\hline $\begin{array}{l}\text { Variation 1: } \\
\text { Globally unique donation, } \\
\text { product \& "key" codes }\end{array}$ & $\begin{array}{l}\text { Country ID + CA } \\
+ \text { TE "key code" }\end{array}$ & $\begin{array}{l}\text { Globally unique } \\
\text { Donation Code }\end{array}$ & $\begin{array}{l}\text { Globally unique } \\
\text { Product Code }\end{array}$ \\
\hline $\begin{array}{l}\text { Variation 2: } \\
\text { National, regional, or local } \\
\text { donation code + globally } \\
\text { unique product \& "key" codes }\end{array}$ & $\begin{array}{l}\text { Country ID + CA } \\
+ \text { TE "key code" }\end{array}$ & $\begin{array}{c}\text { National, Regional, } \\
\text { or Local Donation } \\
\text { Code } \\
\end{array}$ & $\begin{array}{l}\text { Globally unique } \\
\text { Product Code }\end{array}$ \\
\hline $\begin{array}{l}\text { Variation 3: } \\
\text { National, regional, or local } \\
\text { donation \& product codes + } \\
\text { "key" code }\end{array}$ & $\begin{array}{l}\text { Country ID + CA } \\
+ \text { TE "key code" }\end{array}$ & $\begin{array}{c}\text { National, Regional, } \\
\text { or Local } \\
\text { Donation Code } \\
\end{array}$ & \begin{tabular}{|c|} 
National, Regional, \\
or Local \\
Product Code \\
\end{tabular} \\
\hline
\end{tabular}

Fig. 2. Proposed alternative structures of the EU code. Country ID = Country Identification acc. ISO 3166-1; CA = Competent Authority; $\mathrm{TE}=$ tissue establishment.
The second character of Eurocode data structures (secondary identifier), which directly follows the primer identifier '!', determines the various data elements, e.g.:

- numeric character $=$ unique product identification number (or donation number),

- $\mathrm{P}, \mathrm{Q}, \mathrm{p}=$ product codes (for international, national and internal applications),

- C and D = collection date (with and without hour),

- E and F expiry date (with and without hour).

Following the primary identifier '!', the unique product identification number for blood products includes the country code indicated in ISO 3166-1 as a three digit numeric code (2 or 3 alpha characters are also defined as country codes in the ISO 3166-1). This is followed by a center code, a serial donation number, a flag, and a check digit corresponding to ISO $7064[4,5]$. The technical specification is published online via $w$ ww.eurocode.org.

\section{Aims and Requirements of EU-Directives for Cells and Tissues}

The European Union (EU) described in Commission Directives 2004/23/EC and 2006/86/EC the aim and the requirements for the coding of cells and tissues $[1,7]$ :

'Member States shall ensure that all tissues and cells procured, processed, stored or distributed on their territory can be traced from the donor to the recipient and vice versa. This traceability shall also apply to all relevant data relating to products and materials coming into contact with these tissues and cells. Member States shall ensure the implementation of a donor identification system which assigns a unique code to each donation and to each of the products associated with it. The Commission, in cooperation with the Member States, shall design a single European coding system to provide information on the main characteristics and properties of tissues and cells' [1].

Directive 2006/86/EC determines the information required to be included in the European Coding System. A unique ID number and identification of the tissue establishment for do- nation identification is required, as well as a product code in a basic nomenclature, a split number (flag), and an expiry date for the product identification [6].

\section{EU Initiatives to Implement the Directives on Cells and Tissues}

The EU and the European Commission Directorates have supported the implementation of these Directives by means of various initiatives.

\section{DG SANCO and CEN/ISSS Workshop}

Since 2006 the Directorate General for Health and Consumer Affairs (DG SANCO) together with the European Committee for Standardization (CEN) and the International Society for Systems Sciences (ISSS) has organized several workshops to look at the requirements and potential alternatives for a standardized coding system to handle tissue and cells within Europe. Following the advice and involvement of numerous organizations, including Eurocode, a workshop agreement was published in 2008. This contained diverse suggestions, which all included the idea of an initial key code (fig. 2). The workshop participants generally favored 'Variation 1', with ISBT Code 128 as a globally unique donation code [7]. After further evaluations initiated and discussed by the $D G$ SANCO Working Group on the European Coding System for Human Tissues and Cells, most recently at a meeting on May 19, 2010 in Brussels, 'Variation 2' has become the focus of discussion. A final decision at a European level has not yet been made.

After consultation and discussion with representatives of tissue-handling facilities, the German Federal Ministry for Health decided to lend their support to 'Variation 3', with Eurocode as a Unique Donation Number (UDN) and a national product code for Germany. It was agreed that a single international product code (such as in 'Variation 2') was desirable and will be supported by Germany, although this should give only basic product characteristics, and should be freely available worldwide without charge in electronic format. 


\section{DG INFSO and EUROCET}

Since 2005 the Directorate General Information Society and Media (DG INFSO) has supported a project to collect and publish official and updated figures on organ, tissue and cell donations, and transplantation activities. The project has also established a tissue establishment registry, in which center codes have already been assigned to individual institutions in the 17 EU member countries. These institutions are encoded in ISO 3166-1 by means of two alpha characters and a serial four-digit number. The project coordinator is the National Italian Transplant Center [8].

To aid the matching of data to the registered establishments it makes sense to employ the EUROCET registry number as center code in the data structure of the UDN.

\section{EUSTITE}

The primary objective of the funded project 'European Union Standards and Training in the Inspection of Tissue Establishments' (EUSTITE) was to optimize and harmonize the standards and methods applied by Competent Authorities in the inspection and accreditation of tissue procurement and tissue establishments within the EU. A secondary objective was to propose common systems for definition, classification and reporting of adverse events and reactions that are consistent with similar systems in other parts of the world. The project ran from 2006 to 2009 and was coordinated by the National Italian Transplant Center [9].

\section{Implementation of EU Regulations in Eurocode}

In 2008 and 2009 Eurocode IBLS and the Working Parties 'Tissue Preparations' and 'Automation and Data Processing' of the German Society of Transfusion Medicine and Immunohematology (DGTI) jointly developed the data structure for the encoding of tissues which met the requirements set out in the EU Directive. In the Working Party 'Tissue Preparations' of the DGTI are representatives from all type of tissues and from several German tissue establishments. According to the data from the German responsible authorities, about 600 tissue establishments are registered today.

\section{$U D N$}

In incorporating an UDN (in the Eurocode guidelines: unique product identification number), the agreement at the DG SANCO meeting held on May 19, 2010 in Brussels took into account the CEN/ISSS workshop agreements and the EUROCET registry number for tissue and cell establishments, now extended up to 6 digits for the center codes. The Competent Authority should in future be stored in the EUROCET registry along with the center code, in order to avoid lengthening the barcode unnecessarily (fig. 3).

Eurocode unique product identification number meets the requirements of a UDN in term of the unique identification of

\section{!T cc iiiiii yy nnnnnnn p !P nnnnnn !E yy mm do}

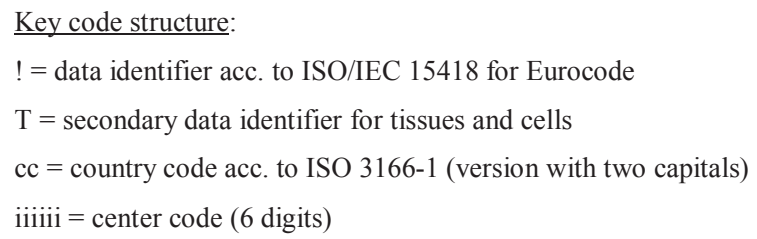

Fig. 3. UDN in Eurocode.

the producer and a clear product identification number. The previously unused character ' $\mathrm{T}$ ' was adopted as a secondary identifier to distinguish the UDN for cells and tissues from other data elements. The number of characters contained in the serial number ( $\mathrm{n}$ ) is sufficient for 10 million tissue and cell products each year and for each center. This serial number can be increased at any time following international agreement and the introduction of a transition period.

\section{Split Numbers}

The UDN for every product must be unique, regardless of whether several products issue from one donation event. A division of the UDN into one section which encodes the donation, and another which encodes the resulting product by means of a split number or flag, is no longer required by the DG SANCO Working Group due to the different Data Protection Acts in the member states. Every member state can decide whether to use the solution described above (UDN, fig. 3) or below (fig. 4). The description under figure 4 shows only an example of how member states can implement a split number into the Eurocode data structure. The number of digits for ' $\mathrm{n}$ ' and ' $\mathrm{f}$ ' can be chosen by the member states as long as the stipulated barcode length is not exceeded (fig. 1). 


\title{
!T cc iiiiii yy nnnnfff $p$
}

\author{
Key code structure: \\ $!$ = data identifier acc. to ISO/IEC 15418 for Eurocode \\ $\mathrm{T}=$ secondary data identifier for tissues and cells \\ $\mathrm{cc}=$ country code acc. to ISO $3166-1$ (version with two capitals) \\ iiiiii $=$ center code $(4$ digits $)$
}

(cciiiiii acc. EUROCET registry number)

Unique Donation Number:

yy $=$ decade/ year

$\mathrm{n}=$ serial numbers for the donation

$\mathrm{f}=$ serial number for the products prepared from one donation (flag or split

number)

$\mathrm{p}=$ check digit by MOD11.10 by ISO 7064

Fig. 4. Possible use of UDN with split numbers in Eurocode.
2007 regarding the purpose of CEN/ISSS: 'Donor confidentiality is a legal requirement of most organ and cell legislative environments globally. The conflict between the need to be able to identify the donor and the need to be able to maintain confidentiality is not clearly enunciated in your documents. In the context of cord blood or hematopoietic stem cells there is an absolute need to retain confidentiality even of the country of origin. Do not underestimate the degree to which individuals will strive to discover the identity of a donor.'

In the previously described approach the donation code would not be made public, but instead the link between donor, donation number and derived products would be securely stored, either electronically or in paper format, by the tissue establishments. This does not affect the traceability of products, as this is ensured by the tissue establishments. The information that two products have been derived from one donation is seen as irrelevant to the user.

\section{Product Code}

A further important aspect of the EU Directives, and a concern of the World Health Organization (WHO), is the demand for a standard encoding and description of product characteristics in the product code, in order to register and evaluate the use of individual products and their side effects. This requires a clear classification of products into a limited number of groups, along the lines of the International Classification of Diseases (ICD) [10]. However, for the user of products, such a classification is insufficient as it does not supply the necessary depth of detail. There are three solutions to this problem: the shorter international classification can be separately noted on the product, it can be inserted into the existing system of product coding, or the supplier of the cod- 
ing system can provide a 'classification table' in which the 'internal' product code is matched to an international classification. The addition of an extra-classification, the integration of an international classification into the product code as well as the provision of a classification table are all solutions which can be accommodated by Eurocode. It is vital that any solution ensures that all users have free online access to the international product classification as well as to the product codes of individual suppliers.

Today the Eurocode system defines 17 different groups of characteristics (so-called qualifiers) for blood products, e.g. the type of donation. These qualifiers are classified using serial numbering according to likely concrete characteristics, e.g. allogeneic. The relevant characteristic must be defined for each qualifier, or the indication 'not specified' or 'not applicable' must be chosen. If no complete match with all qualifiers can be found for a particular product, then a new six-figure product code is assigned. One million product codes can be assigned within Eurocode. Up to now 459 different products have been registered.

It is planned to expand the number of qualifiers for tissues and cells from 17 to 18 , while the tables for 8 qualifiers will be enlarged to include additional characteristics. The qualifier 'Tissue', which has been available since 1998, now includes a total of 70 different types of tissue which have been defined by members of the DGTI Working Party 8 'Tissue Preparations' as relevant for clinical use. This table can be extended at any time to include additional types of tissues. According to current projections, Eurocode expects to register an additional 200 to 250 product codes for the characterization of tissue type.

The suggestions made by the DGTI Working Party 'Tissue Preparations' and the technical commission of Eurocode were confirmed by the Eurocode board meeting of March 9-10, 2010 and at the current time are being introduced into specifications and onto the website. In order to avoid hindering any international agreement regarding product codes, Eurocode has so far refrained from publishing any product codes for tissues and cells. However, as this fact is frequently used by interested parties as an argument against Eurocode, it has now been decided to publish such codes from the middle of 2010 .

\section{Conclusion}

The worldwide exchange of tissues and cells of human origin requires the clear identification of products in order to avoid confusion and to facilitate the look back process. EU Directives 2004/23/EC and 2006/86/EC have given some legal backing to this within the European Union. The desire for a single, standardized EU-wide system was also expressed in the documentation. However, as several member states already use their own national systems to identify products of biological products, agreement on the implementation of one single sys- tem has still not been reached 3 years after the original deadline set by the Directives. The CEN/ISSS workshop organized under the auspices of the EU pointed to possible variations in its workshop agreement of 2008, recommending ISBT-Code 128 for general use. After further evaluations initiated and discussed by the DG SANCO Working Group on the European Coding System for Human Tissues and Cells, most recently at a meeting on May 19, 2010 in Brussels, 'Variation 2' of the CEN/ISSS workshop agreement with a proposed key code, a national UDN and a basic 'European' product code for tracing has become the focus of discussion. A final decision at a European level has not yet been made. 'Variation 2' would allow the continued use of national UDNs after the key code, thus forming a good basis for a final agreement. Furthermore, the DG SANCO Working Group decided to make use of preliminary work carried out by the EUROCET project for the registration of all tissue establishments in Europe by extending the institute code by up to six digits and incorporating the registration of the competent authority for all centers.

The Eurocode system currently in place in Germany and Croatia meets all requirements of the EU Directive. Its data structure is such that a large increase in individual products (unique production identification number) can be easily incorporated. One major advantage of Eurocode is that the flexible structure following the key code allows the integration of some of the alternative data structures currently employed for identification in different countries, thus ensuring their continued use.

The introduction of an internationally accepted single product code with a classification as demanded by EU Directives can only be welcomed. This system should contain basic information relevant to the user and should be freely available at no charge for the end users. Neither the Eurocode nor the ISBT-Code 128, or indeed any other system known to the author, is capable of meeting these requirements, as the product codes in all cases encode the product characteristics in considerable detail. Eurocode is able at any time to encode a future basic product classification in addition to the product code by using a next secondary identifier after the primer identifier '!'. Currently it would also be feasible to integrate an international classification into the product code. The provision of classification tables which match internal product codes to an international product classification is also possible as well as a separate indication of product classification at a later stage.

The Eurocode system was approved as the single coding system for cells and tissues in Germany by the Working Party 'Tissue Preparations' of the DGTI and by the German Ministry of Health on September 8, 2009.

\section{Disclosure Statement}

The authors declared no conflict of interest. 


\section{References}

1 European Commission: Directive 2004/23/EC of the European Parliament and of the Council on setting standards of quality and safety for the donation, procurement, testing, processing, preservation, storage and distribution of human tissues and cells. EUR-Lex, 2004. http://ec.europa.eu/health ph_threats/human_substance/legal_tissues_cells_ en.htm (accessed November 19, 2009).

2 Joint Technical Committee ISO/IEC JTC 1, Information Technology, Subcommittee SC 31, Automatic Identification and Data Capture Techniques: Information technology - automatic identification and data capture techniques - GS1 application identifiers and ASC MH10 data identifiers and maintenance. ISO/IEC, 2009. http://webstore.iec.ch/ preview/info_isoiec $15418 \% 7$ Bed $2.0 \% 7$ Den.pdf (accessed November 19, 2009).

3 Ashford P, Butch S, Grabowski S, Georgsen J, Muon M, Distler P: ISBT 128 Standard Technical Specification, Version 3.6.0. ICCBBA, 2009. http:// iccbba.org/technicalspecification.pdf_(accessed April 29, 2010).

4 Eurocode-Guideline: Data Structure, Version 1.1.1. Eurocode IBLS e.V., 2004. www.eurocode. org/guides/index.html (accessed April 29, 2010).

5 Knels R, Roos D, Böcker W, Kardoeus J, Becker G: Eurocode blood labeling system - uniform identification and classification of blood products improves transfusion security. Infus Ther Transfus Med 2002;29:226-231

6 European Commission:Commission Directive 2006/86/EC of 24 October 2006 implementing Directive 2004/23/EC of the European Parliament and of the Council as regards traceability requirements, notification of serious adverse reactions and events and certain technical requirements for the coding, processing, preservation, storage and distribution of human tissues and cells. EUR-Lex. 2006. http://ec.europa.eu/health/ph_threats/human_substance/legal_tissues_cells_en.htm. Accessed 19 November 2009

7 CEN/ISSS Workshop Agreement: Coding of information and traceability of human tissues and cells. CEN, 2008. ftp://cenftp1.cenorm.be/PUBLIC/ CWAs/e-Europe/Tissues_cells/CWA15849-2008publishedtext.pdf (accessed November 19, 2009).

8 EUROCET: European Registry for Organs, Tissues and Cells. 2005. www.eurocet.org/ (accessed April 29, 2010).

9 EUSTITE: European Union Standards and Training in the Inspection of Tissue Establishments. 2006. www.eustite.org/ (accessed April 29, 2010).

10 WHO: ICD: International Classification of Diseases.2007. www.who.int/classifications/icd/en/ (accessed April 29, 2010). 